\title{
BOOTS' NEW BIOLOGICAL RESEARCH LABORATORIES
}

\author{
By DR. G. I. HOBDAY \\ Director of Research
}

\begin{abstract}
$\mathrm{D}$ URING a night-time air-raid on Nottingham in May 1941, nearly all the research facilities of Boots Pure Drug Co., Ltd., were destroyed. Blast and fire reduced virtually all the chemical and biological laboratories to heaps of charred rubble. The timing of this disaster could not have been more unfortunate. Under the stimulus of the national emergency we were expanding our research operations to enable the company to manufacture many vital drugs of European origin, supplies of which had been cut off by the War ; penicillin, in the development of which we were to collaborate, was about to emerge. It was urgently necessary, therefore, to re-house our chemists and biologists as soon as possible. Because new construction was out of the question existing premises had to be converted. Choice of these was not easy since the Research Department was by no means the only one to suffer damage and every foot of space in the company's buildings in and around Nottingham was at a premium.
\end{abstract}

After due consideration, it was decided to re-house chemistry and biochemistry in a nearby building on the Island Street site and to evacuate the biological facilities, including bacteriology and pharmacology research and standardization, to a heterogeneous group of company buildings in West Bridgford, a Nottingham suburb. These latter, on which over the years a considerable amount of money has been expended, have served us well. Of course, it was evident from the beginning that they would answer our needs for only a limited period. But, as with many war-time expedients, building restrictions in the post-war years and the subsequent need to share out the capital cake among an increasing number of growing members of the company left us in occupation of them for longer than was originally intended. However, after about eighteen months of active planning we started construction of a new biological research building in September 1956, and occupation of it has just been completed.

The new building, which was designed by Boots' architectural staff, is sited in Nottingham a short distance away from the chemical manufacturing plant, but near enough so that services such as steam, electricity and water are drawn from the central works supply. It is near the present chemical and biochemical research laboratories and immediately adjacent to the site on which these facilities will be re-housed within the next few years. In plan, the building is in the form of an irregular $\mathrm{H}$; one wing of four floors houses administration offices; Medical Department, library, canteen, conference room and a fully equipped lecture theatre seating 200 ; the linking block contains the main staircase and lifts together with lavatories and cloak-rooms ; the other wing, longer than the first and on seven floors with a basement, is entirely laboratories. The total floor area is approximately $90,000 \mathrm{sq}$. ft. Externally, the building is of striking appearance; one wing is of brick and the other is faced with ceramic tiles in a checker-board pattern of grey and yellow. In internal design the administration wing and linking block are fairly conventional, but features of special interest include the pre-stressed concrete main staircase and the undulant ceiling in the canteen. The lecture theatre, which is acoustically designed, is fitted with stackable chairs which can be removed, entirely liberating the floor space for exhibitions, ete. Also to be noted is the pleasant medical and biological library housing 15,000 volumes, the stack room of which is fitted with mechanically operated stacking for economy of floor space. The décor throughout is modern, but not aggressively so, using mainly monochromatic treatments and avoiding disturbing colour contrasts. In the entrance lobby is a large colourful mural, abstract in design but intelligibly depicting the scientific disciplines provided for in the building.

The laboratory wing is funetionally planned to accommodate the biological procedures employed, the common links throughout being laboratory animals and micro-organismal techniques. Required floor area and available site area comparison clearly pointed to a multi-storey building; this was quite acceptable, indeed in many respects desirable, since it permitted a plan of isolation of different functions on separate floors while reducing circulation distances

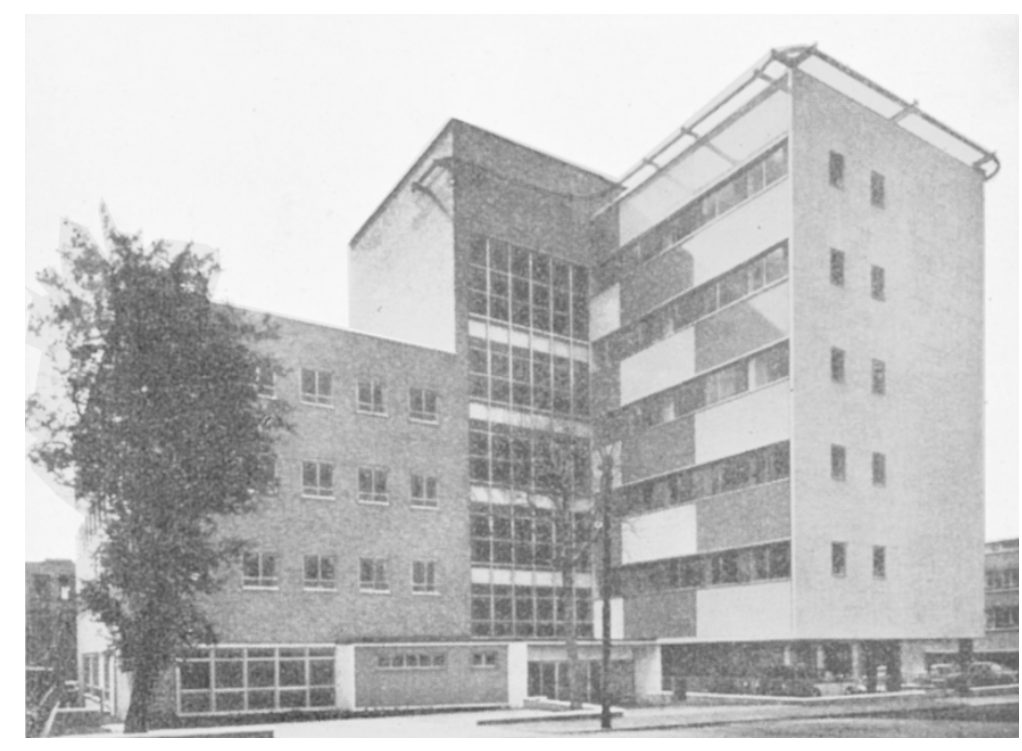

Fig. 1. Main entrance to Boots' Biological Research Laboratories. Administrative offices, library and lecture theatre are on the left; laboratories on the right 
and simplifying centralized servicing. The floors were planned on a 9 -ft. module in a block $200 \mathrm{ft}$. long and $45 \mathrm{ft}$. wide. This plan gave a spinal corridor arrangement which again helped in the separation of functions, since it was easy to form the areas at both ends into isolation units. A steel-framed building was chosen with space-frame girders $3 \mathrm{ft}$. 6 in. deep and $45 \mathrm{ft}$. span. By this arrangement none of the internal walls is part of the structure, permitting alteration of the working areas as the need arises; it also provides a space between ceiling and floor above in which services are distributed. Vertical distribution of services is through a duct, $10 \mathrm{ft}$. by $17 \mathrm{ft}$. , which goes right through the building from top floor to basement. The whole of the laboratory wing is air-conditioned, inlet air being drawn in through an electrostatic precipitator and distributed through two separate systems, one serving the east side and the other the west side to give flexibility in taking care of solar gain through the large unopenable windows. A plenum system is used with pressure differences carefully arranged especially in laboratories where micro-organisms are used. All extracted air from areas of possible infection is filtered sterile before being vented to atmosphere. Where necessary, 'hospital' finishes on walls and ceiling are employed to facilitate cleaning and sterilizing; floor coverings are sheet polyvinylchloride in laboratories and hard asphalt in animal rooms and wash-down areas. Stainless steel benches and steel under-bench fittings are employed in all sterile areas and teak tops with wooden furniture elsewhere.

Equipment cleaning and sterilizing are centralized in the basement, where all refuse is incinerated. There are two systems of automatic hoists for handling separately dirty equipment to the basement and returning clean equipment to the requisite floors. All equipment and material passing from the isolation areas are heat-sterilized before proceeding down the 'dirty' hoist. Media-making is centralized and from a food store on the top floor animal diets are delivered to appropriate floors by chutes.

Facilities for work with radioactive labelled substances are provided in a self-contained suite. The main units of this are a synthetic chemical laboratory, a biological laboratory with separately vented cage cabinets and a radioactivity measurement laboratory. The main radioactive store is in a shielded room in the basement.

The work in the laboratories lies in the fields of pharmacology, toxicology, bacteriology, mycology, virology and parasitology. Some routine testing and standardization work is done on chemical and pharmaceutical production material, such as sterilitytesting of injections and bio-assay of insulin. Otherwise the work is investigation, much of it comprising the biological component of research projects involving other research divisions. For example, in the field of parasitology trypanosomiasis is a major project, and chemical substances synthesized in the nearby chemical research laboratories, or new antibiotics isolated in the antibiotic research unit, are screened in the new building by specialized laboratory tests. Those of potential value will undergo more specific tests for activity and, in another unit in the building, for toxicity. Any worthy of elinical or field trial will be passed over either to the Medical Department or to the veterinary research division at Thurgarton, about ten miles outside the city. Work of this kind has produced 'Ethidium' and 'Prothidium' for treatment and prophylaxis of bovine trypanosomiasis. In a similar way the parasitologists working on amobiasis have contributed to the development of 'Entamide' for the treatment of amcebiasis. Likewise the bacteriologists have col. laborated with the chemists and pharmacists in developing a new antibacterial substance, 'Dybenal'.

Team operations of this kind provide much of the impetus for progress in the search for new substances for the treatment of human, veterinary and plant diseases. The new laboratories form a vital link in the chain of investigations between the first conception of a new drug and its final availability to the public. They serve the future in providing the type of working accommodation which the young research scientists of to-day expect and need in order to make their most effective contributions in the fight against disease.

\section{THE BRITISH FOOD MANUFACTURING INDUSTRIES RESEARCH ASSOCIATION}

\begin{abstract}
$\mathrm{T}$ HE British Food Manufacturing Industries Research Association Laboratories at Leatherhead were open to members on September 16 and to invited guests on the following day. The wide range of the research programme of the Association was demonstrated, the exhibits covering work in progress for the eight main groups into which the membership is divided, that is to say, cocoa and chocolate, sugar confectionery, meat and fish products, jams and jellies, pickles and sauces, oils and fats (including margarine and compound cooking fats), bakers' prepared materials and miscellaneous products ranging from table jellies to salted nuts and potato crisps. The work undertaken covers funda. mental chemical, physical and bacteriological investigations alongside technological aspects of food manufacture.
\end{abstract}

For the chocolate industry an item of major importance is the study of the rheology of molten chocolate. An experimental viscometer was on show which had been designed and built to the requirements of the Association to give measurements of viscosity over a wide range of rates of shear. A method of plotting the viscometric data has been developed which leads to the flow properties of chocolate being expressible in terms of two constants. The glyceride composition of cocoa butter is being studied by chromatographic techniques. Complete separation of the mono-unsaturated triglycerides has been achieved by reverse phase paper chromatography using a non-polar stationary phase and a suitably chosen mobile phase. An investigation into the volatile constituents responsible for the flavour of cocoa and chocolate by gas chromatography is in its initial stage.

The properties of high-boiled sweets, particularly their behaviour on exposure to the atmosphere, is being investigated by means of an apparatus which 